\title{
FUNGSI GREEN UNTUK PERSAMAAN DIFUSI-ADVEKSI DENGAN SYARAT BATAS DIRICHLET
}

\author{
Green's Function for Diffusion-Advection Equation \\ with Dirichlet Boundary Conditions
}

\author{
Josua $^{1^{*}}$, Evi Noviani ${ }^{2}$, Fransiskus Fran ${ }^{3}$ \\ ${ }^{1,2,3}$ Prodi Matematika, Fakultas Matematika dan Ilmu Pengetahuan Alam, Universitas Tanjungpura \\ Jl. Prof. Dr. H. Hadari Nawawi, Pontianak, 78124, Indonesia
}

e-mail: 1*josua.hillsong@student.untan.ac.id; 2 evi_noviani@math.untan.ac.id; 3 frandly88@gmail.com Corresponding author*

\begin{abstract}
Abstrak
Difusi-adveksi merupakan proses transportasi materi dari satu bagian sistem ke bagian yang lain sebagai hasil dari gerakan molekul acak yang melibatkan proses transportasi fluida dalam bentuk aliran rata-rata atau arus yang dipengaruhi oleh gaya gravitasi atau tekanan dan berupa gerak horizontal. Secara matematis, persamaan difusi-adveksi dapat ditulis sebagai $u_{t}+V u_{x}=D u_{x x}$, dengan $u$ adalah konsentrasi zat dalam fluida, $V$ adalah kecepatan adveksi, dan $D$ adalah koefisien difusi. Dalam tulisan ini, dicari solusi $u(x, t)$ dengan menggunakan konsep fungsi Green. Solusi umum fungsi Green dapat dicari dalam dua bagian yaitu solusi principal dan solusi reguler. Solusi principal diperoleh dengan menerapkan tranformasi Fourier terhadap variabel $\xi$ yang dinotasikan dengan $\hat{U}$ dan kemudian menghitung invers dari transformasinya. Solusi reguler diperoleh berdasarkan pendekatan inspeksi yang dirancang pada sumber panas negatif.
\end{abstract}

Kata Kunci : solusi principal, transformasi Fourier, solusi reguler

\begin{abstract}
Diffusion-advection is the process of transportation of matter from one part of a system to another as a result of random molecular motions involving fluid transport processes in the form of mean flow or currents which are driven by gravity or pressure forces and in the form of horizontal motions. Mathematically, diffusion-advection equation can be written as $u_{t}+V u_{x}=D u_{x x}$, where $u$ is concentration of material in the fluid, $V$ stands for the advection velocity, and $D$ for diffusion coefficient. In this paper, a solution $u(x, t)$ is sought by using the Green's function concept. The general solution for Green's function that can be solved in two parts, namely, the principal solution and the regular solution. The principal solution is obtained by applying the Fourier transform to the variable $\xi$ which is denoted by $\hat{\mathrm{U}}$ and then calculate the inverse of its transform. A regular solution is obtained based on an inspection approach that is designed on a negative heat source.
\end{abstract}

Keywords: principal solution, Fourier transform, regular solution 


\section{PENDAhULUAN}

Persamaan diferensial parsial adalah persamaan diferensial yang melibatkan turunan parsial dari satu atau lebih variabel terikat dengan lebih dari satu variabel bebas. Persamaan diferensial dapat digunakan untuk memodelkan permasalahan sehari-hari yang biasa ditemukan seperti konduksi panas pada batang atau lempengan, menentukan muatan atau arus dalam rangkaian listrik, menentukan getaran kawat atau membran, tingkat pertumbuhan populasi, dan masih banyak lagi. Salah satu contoh permasalahan yang dapat dimodelkan dalam persamaan diferensial adalah difusi dan adveksi. Difusi adalah proses transportasi materi dari suatu sistem ke bagian yang lain sebagai hasil dari gerakan molekul acak [3]. Dalam [11] ditemukan bahwa masing-masing partikel difusi bergerak secara acak di bidang difusi. Sedangkan, adveksi merupakan proses transportasi berupa aliran rata-rata atau arus, seperti sungai atau gerakan pasang surut yang digerakkan oleh gaya gravitasi atau tekanan dan berupa gerak horizontal [13]. Menurut [4] dalam tulisannya tentang persamaan adveksi linier pada bidang kecepatan acak, persamaan adveksi muncul dalam pemodelan berbagai fenomena yang melibatkan transportasi zat secara progresif atau gerakan gelombang.

Persamaan difusi-adveksi merupakan model matematika yang menggambarkan proses transportasi suatu zat yang dipengaruhi gaya gravitasi dan penyebaran sekaligus [10]. Model difusi-adveksi dapat ditemukan dalam kehidupan sehari-hari seperti pencemaran sungai maupun kebakaran hutan. Konsentrasi polutan di dalam air maupun udara pada posisi $x$ dan pada saat $t$ dapat diketahui melalui solusi dari model persamaan difusi-adveksi yang dinotasikan dengan $u(x, t)$. Dalam tulisan [8] tentang difusi-adveksi dalam aliran balik dan osilasi menyebutkan bahwa analisis tentang difusi dan adveksi dua dimensi dalam aliran balik termotivasi oleh kebutuhan untuk memahami dispersi limbah di perairan pasang surut. Sumber titik melepaskan kontaminan ke dalam aliran ini pada tingkat yang stabil, sehingga air yang dekat dengan sumber di sekitar waktu pembalikan aliran akan menjadi sangat terkontaminasi. Persamaan difusi-adveksi adalah salah satu bentuk dari persamaan diferensial parsial dan solusinya dapat berupa fungsi Green. Fungsi Green adalah solusi untuk masalah nilai awal atau nilai batas linier pada persamaan diferensial parsial atau persamaan diferensial biasa [2]. Menurut [9] dalam tulisannya tentang transportasi zat terlarut yang dimodelkan dengan fungsi Green dan penerapannya untuk sumber zat terlarut, model analitik dapat menjadi alat yang berharga untuk menyelidiki transportasi zat terlarut dalam media berpori. Fungsi Green diaplikasikan untuk memfasilitasi solusi analitik dari persamaan adveksi-dispersi untuk transportasi zat terlarut dalam media berpori yang seragam dengan aliran satu atau dua dimensi yang stabil. Fungsi Green dengan mudah menangani syarat awal dan batas yang berbeda serta masalah multi-dimensi.

Tulisan ini bertujuan untuk mengkaji penentuan fungsi Green sebagai solusi dari persamaan difusiadveksi. Fungsi Green pada tulisan ini merupakan solusi dari persamaan difusi-adveksi pada syarat batas umum di posisi $x$ dan waktu $t$, sehingga menjadi modal bagi penyelesaian persamaan difusi-adveksi untuk kondisi atau syarat batas yang lebih khusus. Persamaan difusi-adveksi yang dibahas dalam tulisan ini adalah persamaan difusi-adveksi satu dimensi dan syarat batas yang digunakan adalah syarat batas Dirichlet pada domain semi-tak hingga. Dirichlet merupakan salah satu syarat batas yang diperlukan untuk menentukan solusi dari persamaan diferensial parsial.

\section{METODE PENELITIAN}

Persamaan difusi-adveksi satu dimensi dapat ditulis sebagai berikut:

$$
u_{t}+V u_{x}=D u_{x x} \text {, }
$$

dengan $V$ adalah kecepatan adveksi dan $D$ adalah koefisien difusi. Untuk mendapatkan solusi dari Persamaan (1), terlebih dahulu ubah persamaan tersebut dalam bentuk operator diferensial $L$. Langkah selanjutnya adalah membentuk operator adjoin $L^{*}$, yaitu dengan mengalikan suatu fungsi sebarang pada bentuk operator diferensial dari persamaan difusi-adveksi dan diselesaikan menggunakan integral parsial. Kemudian, konsep fungsi delta Dirac diterapkan pada operator adjoin untuk mendapatkan solusi umum persamaan difusi-adveksi. Setelah itu, domain semi-tak hingga dan syarat batas Dirichlet diterapkan pada solusi umum persamaan difusi-adveksi. Fungsi sebarang yang dikalikan pada persaamaan difusi-adveksi dipilih sebagai fungsi Green sedemikian memenuhi masalah adjoinnya. Solusi bagi masalah adjoin tersebut dapat dicari dalam dua bagian, yaitu solusi principal dan solusi reguler. Solusi principal merupakan solusi dari bentuk tak homogen persamaan diferensial tanpa memperhatikan syarat batas. Solusi principal pada tulisan ini diperoleh dengan menerapkan tranformasi Fourier terhadap variabel $\xi$ yang dinotasikan dengan

$\hat{U}$ dan kemudian menghitung invers dari transformasinya. Sedangkan, solusi reguler merupakan solusi dari bentuk homogen persamaan diferensial dengan syarat batas. Solusi reguler diperoleh berdasarkan pendekatan 
inspeksi yang dirancang pada sumber panas negatif. Setelah diperoleh solusi principal dan solusi reguler, fungsi Green didapatkan dengan menjumlahkan keduanya. Terakhir, jika fungsi Green disubstitusikan ke solusi umum persamaan difusi-adveksi pada domain semi-tak hingga dan syarat batas Dirichlet, maka solusi persamaan difusi-adveksi dapat diperoleh dengan menyelesaikan integrasinya. Langkah-langkah penyelesaian dalam tulisan ini merujuk pada [15].

\section{HASIL DAN PEMBAHASAN}

\subsection{Solusi Persamaan Diferensial Parsial dengan Melibatkan Fungsi Green}

Fungsi Green pertama kali diperkenalkan oleh George Green (1793-1841) dalam karyanya tentang aplikasi analisis matematika untuk teori listrik dan magnet. Fungsi Green hanya berlaku ketika operator diferensial memenuhi prinsip superposisi yang menyatakan bahwa jika $u_{1}, \ldots, u_{n}$ merupakan solusi, maka kombinasi liniernya

$$
c_{1} u_{1}(x)+\ldots+c_{n} u_{n}(x)=\sum_{j=1}^{n} c_{j} u_{j}(x) \quad\left(c_{j}=\text { konstanta }\right)
$$

juga merupakan solusi [14]. Sebagian besar operator dalam persamaan difusi, persamaan gelombang, persamaan Laplace, semua persamaan diferensial parsial linier orde dua memenuhi persyaratan tersebut [15].

Persamaan diferensial parsial linier orde dua dengan dua variabel bebas $x$ dan $y$ ditulis sebagai berikut [7]

$$
L u=A u_{x x}+2 B u_{x y}+C u_{y y}+D u_{x}+E u_{y}+F u=\phi,
$$

dengan $A, B, C, D, E, F$, dan $\phi$ adalah fungsi dari $x$ dan $y$, serta $L$ adalah suatu operator diferensial. Persamaan (2) berlaku untuk daerah $\mathcal{R}$ pada kurva batas $\mathcal{B}$, seperti yang ditunjukkan pada Gambar 1.

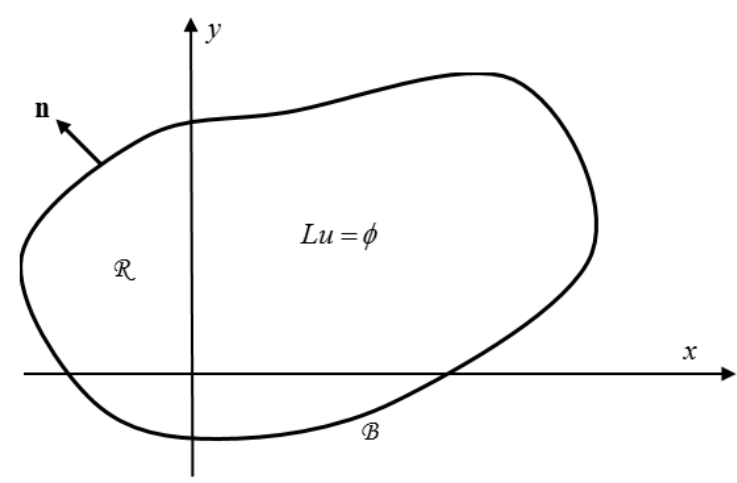

Gambar 1. Masalah Nilai Batas Umum [6]

Berdasarkan konsep hasil kali dalam [1] dan operator adjoin [12], yaitu:

dan

$$
(f, g)=\int_{a}^{b} f(x) g(x) d x
$$

$$
(v, L u)=\left(L^{*} v, u\right)
$$

dapat dicari operator adjoin diferensial $L^{*}$ dengan membentuk perkalian $v L u$, diperoleh

$$
\iint_{\mathcal{R}} v L u d \sigma=\int_{\mathcal{B}}(M \mathbf{i}+N \mathbf{j}) \cdot \mathbf{n} d s+\iint_{\mathcal{R}} u L^{*} v d \sigma
$$

dengan $d \sigma$ adalah elemen diferensial di daerah $R, d s$ adalah elemen diferensial di sepanjang busur $\mathscr{B}$ $d y=\mathbf{n} \cdot \mathbf{i} d s, d x=\mathbf{n} \cdot \mathbf{j} d s$, dan

$$
\begin{gathered}
L^{*} v=(A v)_{x x}+2(B v)_{x y}+(C v)_{y y}-(D v)_{x}-(E v)_{y}+F v, \\
M=A v u_{x}-(A v)_{x} u+2 B v u_{y}+D v u \\
N=-2(B v)_{x} u+C v u_{y}-(C v)_{y} u+E v u
\end{gathered}
$$

Misalkan dipilih $v=v(\xi, \eta)$ sedemikian sehingga

$$
L^{*} v=\delta(\xi-x, \eta-y) .
$$


Perhatikan integrasi kedua dari (3). Dengan mensubstitusikan (4) dan mengganti variabel integrasi $(x, y)$ dengan variabel dummy $(\xi, \eta)$, diperoleh

$$
\iint_{\mathbb{R}} u L^{*} v d \sigma=\iint_{\mathbb{B}} u(\xi, \eta) \delta(\xi-x, \eta-y) d \xi d \eta
$$

Dengan menerapkan sifat fungsi delta Dirac [5]

$$
\int_{-\infty}^{+\infty} \int_{-\infty}^{+\infty} f(x, y) \delta(x-a, y-b) d x d y=f(a, b)
$$

untuk setiap $f$ fungsi yang kontinu pada daerah di sekitar titik asal, maka diperoleh

$$
\iint_{\mathcal{R}} u L^{*} v d \sigma=\iint_{\mathcal{B}} u(\xi, \eta) \delta(\xi-x, \eta-y) d \xi d \eta=u(x, y),
$$

dengan $u$ kontinu pada daerah $\mathcal{R}$ yang berisi titik $(\xi, \eta)$. Fungsi $v(\xi, \eta ; x, y)$ dipilih sebagai fungsi Green $G(\xi, \eta ; x, y)$, sedemikian sehingga memenuhi

$$
L^{*} G=\delta(\xi-x, \eta-y) .
$$

Secara umum, lebih mudah untuk menentukan fungsi $G$ dari (6) dalam dua bagian, yaitu [6]

$$
G(\xi, \eta ; x, y)=U(\xi, \eta ; x, y)+g(\xi, \eta ; x, y),
$$

dengan $U$ adalah solusi principal dari Persamaan (6) tanpa syarat batas, sedangkan $g$ adalah solusi reguler dari persamaan homogen $L^{*} G=0$ dengan syarat batas, sehingga jumlahan $U+g$ memenuhi syarat batas $G$. Selanjutnya, jika Persamaan (5) disubstitusikan ke (3) dan $v$ diganti dengan $G$, serta diketahui $L u=\phi$, maka diperoleh solusi dari Persamaan (2) yaitu:

$$
u(x, y)=\iint_{\mathcal{R}} G \phi d \sigma-\int_{\mathcal{B}}(M \mathbf{i}+N \mathbf{j}) \cdot \mathbf{n} d s,
$$

dengan dimana $\mathbf{n}$ adalah vektor normal, $\mathbf{i}$ adalah vektor yang bersesuaian dengan sumbu $x$, dan $\mathbf{j}$ adalah vektor yang bersesuaian dengan sumbu $y$.

\subsection{Solusi Persamaan Difusi-Adveksi Satu Dimensi}

Persamaan difusi-adveksi merupakan suatu persamaan yang memuat sifat persamaan difusi dan persamaan adveksi [10]. Bentuk dari persamaan difusi-adveksi adalah sebagai berikut:

$$
u_{t}+V u_{x}=D u_{x x},
$$

dengan $V$ adalah kecepatan adveksi dan $D$ adalah koefisien difusi, keduanya dianggap sebagai konstanta. Persamaan difusi-adveksi (9) dapat ditulis sebagai

$$
L u=u_{t}+V u_{x}-D u_{x x}=\phi(x, t)
$$

dengan $\phi(x, t)$ adalah istilah injeksi untuk massa zat terlarut dalam domain tak hingga. Persamaan difusiadveksi berlaku untuk daerah $\mathcal{R}$ dan domainnya ditentukan sebagai daerah persegi panjang (Gambar 2), yaitu: $x_{1}<x<x_{2}$ dan $t_{1}<t<t_{2}$.

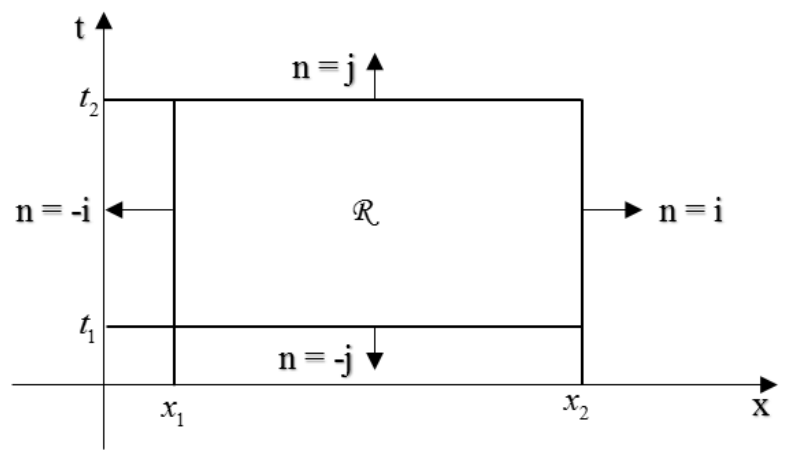

Gambar 2. Daerah Persegi Panjang untuk Difusi-Adveksi [15]

Kemudian, dengan merujuk pada Subbab 3.1, dicari operator adjoin diferensial $L^{*}$ dengan membentuk perkalian $v L u$ dan dengan menggunakan integral parsial, diperoleh

$$
\iint_{R} v L u d \sigma=\int_{x_{1}}^{x_{2}}\left(\left.v u\right|_{t_{1}} ^{t_{2}}\right) d x+\int_{t_{1}}^{t_{2}}\left[\left.V v u\right|_{x_{1}} ^{x_{2}}-\left.D\left(v u_{x}-v_{x} u\right)\right|_{x_{1}} ^{x_{2}}\right] d t+\iint_{R} u L^{*} v d \sigma,
$$

dengan $L^{*} v=-v_{t}-V v_{x}-D v_{x x}$ dan $L^{*}$ adalah operator adjoin dari operator diferensial $L$, ditulis sebagai 


$$
L^{*}=-\frac{\partial}{\partial t}-V \frac{\partial}{\partial x}-D \frac{\partial^{2}}{\partial x^{2}}
$$

Misalkan dipilih $v=v(\xi, \tau)$ sedemikian sehingga

$$
L^{*} v=\delta(\xi-x, \tau-t) \text {. }
$$

Perhatikan integrasi ketiga dari (11). Dengan mensubstitusikan (13) dan mengganti variabel integrasi $(x, t)$ dengan variabel dummy $(\xi, \tau)$, diperoleh

$$
\iint_{R} u L^{*} v d \sigma=\int_{t_{1}}^{t_{2}} \int_{x_{1}}^{x_{2}} u(\xi, \tau) \delta(\xi-x, \tau-t) d \xi d \tau
$$

Dengan menerapkan sifat fungsi delta Dirac, maka Persamaan (14) menjadi

$$
\iint_{R} u L^{*} v d \sigma=\int_{t_{1}}^{t_{2}} \int_{x_{1}}^{x_{2}} u(\xi, \tau) \delta(\xi-x, \tau-t) d \xi d \tau=u(x, t),
$$

untuk setiap $u$ kontinu pada daerah $R$ yang berisi titik $(\xi, \tau)$. Fungsi $v(\xi, \tau ; x, t)$ dipilih sebagai fungsi Green $G(\xi, \tau ; x, t)$, sedemikian sehingga memenuhi

$$
L^{*} G=\delta(\xi-x, \tau-t)
$$

Kemudian, dengan mensubstitusikan $v$ sebagai $G$ ke Persamaan (11) dan diketahui $L u=\phi$, serta mengubah variabel $(x, t)$ menjadi variabel dummy $(\xi, \tau)$, maka diperoleh

$$
u(x, t)=\iint_{R} G \phi d \xi d \tau-\int_{\xi_{1}}^{\xi_{2}}\left(\left.G u\right|_{\tau_{1}} ^{\tau_{2}}\right) d \xi-\int_{\tau_{1}}^{\tau_{2}}\left[\left.V G u\right|_{\xi_{1}} ^{\xi_{2}}-\left.D\left(G u_{\xi}-G_{\xi} u\right)\right|_{\xi_{1}} ^{\xi_{2}}\right] d \tau .
$$

Sehingga, solusi dari Persamaan (10) akan didapatkan setelah solusi dari Persamaan (16) diketahui. Secara khusus, solusi Persamaan (10) dapat dihitung melalui (17).

\subsection{Menentukan Fungsi Green untuk Persamaan Difusi-Adveksi dengan Menggunakan Syarat Batas Dirichlet}

Persamaan difusi-adveksi satu dimensi didefinisikan dalam sumbu semi-tak hingga dengan syarat awal di $t=0$ dan syarat batas di $x=0$. Masalah umumnya dirumuskan sebagai berikut:

$$
\begin{gathered}
L u=u_{t}+V u_{x}-D u_{x x}=\phi(x, t), 0<x<\infty, 0<t<\infty, \\
u(x, 0)=f(x), \\
u(0, t)=h(t) .
\end{gathered}
$$

Jenis kondisi pada Persamaan (19) dan (20) disebut syarat batas Dirichlet. Berdasarkan (17), solusi dari Persamaan (18) dapat ditulis sebagai

$$
u(x, t)=\int_{0}^{\infty} \int_{0}^{\infty} G \phi d \xi d \tau-\left.\int_{0}^{\infty}(G u)\right|_{\tau=0} ^{\tau=\infty} d \xi-\left.\int_{0}^{t}\left(V G u-D G u_{\xi}+D G_{\xi} u\right)\right|_{\xi=0} ^{\xi=\infty} d \tau .
$$

Nilai fungsi $\left.G\right|_{\tau=\infty},\left.G\right|_{\xi=\infty}$, dan $\left.G_{\xi}\right|_{\xi=\infty}$ pada Persamaan (21) dapat ditentukan dengan memahami syarat batas alami fungsi Green di tak hingga. Solusi dari Persamaan (16) adalah fungsi Green $G(\xi, \tau ; x, t)$ yang merupakan distribusi panas berikutnya yang dihasilkan oleh unit dorongan panas sesaat di lokasi $x$ dan pada saat $t$. Selanjutnya, dapat disimpulkan bahwa $\left.G\right|_{\tau=\infty},\left.G\right|_{\xi=\infty}$, dan $\left.G_{\xi}\right|_{\xi=\infty}$ harus nol, karena unit dorongan panas yang diberikan pada lokasi berhingga tidak dapat mempengaruhi distribusi di tempat yang tak hingga jauhnya atau di waktu yang tak hingga lamanya. Oleh karena itu, berdasarkan syarat fungsi Green di tak hingga serta syarat awal (19) dan batas (20) yaitu $u(\xi, 0)=f(\xi)$ dan $u(0, \tau)=h(\tau)$, Persamaan (21) dapat disederhanakan menjadi

$$
\begin{aligned}
u(x, t)= & \int_{0}^{\infty} \int_{0}^{\infty} G(\xi, \tau) \phi(\xi, \tau) d \xi d \tau+\int_{0}^{\infty} G(\xi, 0) f(\xi) d \xi+ \\
& \int_{0}^{t}\left[V G(0, \tau) h(\tau)-D G(0, \tau) u_{\xi}(0, \tau)+D G_{\xi}(0, \tau) h(\tau)\right] d \tau .
\end{aligned}
$$

Pada Persamaan $(22)$, suku $D G(0, \tau) u_{\xi}(0, \tau)$ tidak sesuai dengan syarat batas yang ditentukan yaitu $u(0, \tau)=h(\tau)$. Untuk menghilangkannya, dapat digunakan $G(0, \tau)=0$ sebagai syarat batas untuk 
menentukan G. Jadi, Persamaan (22) dapat disederhanakan lebih lanjut, berdasarkan pada asumsi syarat batas $G$, yaitu:

$$
u(x, t)=\int_{0}^{\infty} \int_{0}^{\infty} G(\xi, \tau) \phi(\xi, \tau) d \xi d \tau+\int_{0}^{\infty} G(\xi, 0) f(\xi) d \xi+\int_{0}^{t}\left[D G_{\xi}(0, \tau) h(\tau)\right] d \tau,
$$

dengan masalah adjoin $G$ yang dirumuskan sebagai

$$
\begin{gathered}
L^{*} G=-G_{\tau}-V G_{\xi}-D G_{\xi \xi}=\delta(\xi-x, \tau-t), 0<\xi<\infty, 0<\tau<\infty, \\
G(0, \tau)=0 .
\end{gathered}
$$

Persamaan (24) dan syarat batas (25) inilah yang selanjutnya digunakan untuk menentukan fungsi Green.

\subsubsection{Solusi Principal}

Merujuk pada Persamaan (7), solusi Green $G$ dari Persamaan (24) terdiri dari solusi principal $(U)$ dan solusi reguler $(g)$, dapat ditulis sebagai:

$$
G(\xi, \tau ; x, t)=U(\xi, \tau ; x, t)+g(\xi, \tau ; x, t) .
$$

Pertama, dicari solusi principal ( $U$ ) dengan menyelesaikan persamaan tak homogen

$$
L^{*} U=-U_{\tau}-V U_{\xi}-D U_{\xi \xi}=\delta(\xi-x, \tau-t),-\infty<\xi<\infty, 0<\tau<\infty,
$$

tanpa syarat batas. Penyelesaian (27) membutuhkan transformasi Fourier dari $\xi$ ke $\omega$. Oleh karena itu, dikalikan $\exp (-i \omega \xi) d \xi$ di kedua sisi Persamaan (27) dan diintegrasikan dari $-\infty$ ke $\infty$, serta menerapkan sifat transformasi Fourier dari fungsi delta Dirac [7]

$$
F[\delta(x-a)]=\int_{-\infty}^{\infty} \exp (-i \xi x) \delta(x-a) d x=\exp (-i a \xi)
$$

sehingga diperoleh

$$
-\int_{-\infty}^{\infty} U_{\tau} \exp (-i \omega \xi) d \xi-V \int_{-\infty}^{\infty} U_{\xi} \exp (-i \omega \xi) d \xi-D \int_{-\infty}^{\infty} U_{\xi \xi} \exp (-i \omega \xi) d \xi=\delta(\tau-t) \exp (-i \omega x) .
$$

Selanjutnya, transformasi Fourier diterapkan pada sisi kiri (29) dengan memisalkan

$$
\hat{\mathrm{U}}(\omega, \tau) \equiv \int_{-\infty}^{\infty} U(\xi, \tau) \exp (-i \omega \xi) d \xi .
$$

Kemudian, dengan menerapkan (30) pada sisi kiri (29), diperoleh

$$
-\frac{d \hat{\mathrm{U}}}{d \tau}+\left(D \omega^{2}-i \omega V\right) \hat{\mathrm{U}}=\delta(\tau-t) \exp (-i \omega x) .
$$

Menurut definisi fungsi delta Dirac [7]

$$
\delta(x-a)=\left\{\begin{array}{ll}
\infty, & \text { jika } x=a \\
0, & \text { jika } x \neq a
\end{array},\right.
$$

sisi kanan Persamaan (31) bernilai nol untuk $\tau>t$ dan $\tau<t$, yaitu:

$$
-\frac{d \hat{\mathbf{U}}}{d \tau}+\left(D \omega^{2}-i \omega V\right) \hat{\mathrm{U}}=0 \text {, jika } \tau>t \text { atau } \tau<t .
$$

Jika variabel $\hat{U}$ dan $\tau$ pada Persamaan (32) dipisahkan kemudian diintegrasikan, maka diperoleh

$$
\hat{\mathrm{U}}=\exp \left(D \omega^{2}-i \omega V\right) \tau \cdot \exp (A) .
$$

Karena Persamaan (32) berlaku untuk dua kondisi yaitu $\tau>t$ dan $\tau<t$, maka (33) dapat ditulis

$$
\hat{\mathrm{U}}=\left\{\begin{array}{l}
A_{1} \exp \left[\left(D \omega^{2}-i \omega V\right) \tau\right], \text { jika } \tau>t, \\
A_{2} \exp \left[\left(D \omega^{2}-i \omega V\right) \tau\right], \text { jika } \tau<t,
\end{array}\right.
$$

dengan $A_{1}$ dan $A_{2}$ adalah konstanta. Untuk menentukan $A_{1}$ dan $A_{2}$, maka dibuat integrasi (31) terhadap $\tau$ pada interval disekitar $t$ dari $\tau=t-0$ sampai $\tau=t+0$, yaitu

$$
-\left.\hat{\mathrm{U}}\right|_{t-0} ^{t+0}+\left(D \omega^{2}-i \omega V\right) \int_{t-0}^{t+0} \hat{\mathrm{U}} d \tau=\exp (-i \omega x) \int_{t-0}^{t+0} \delta(\tau-t) d \tau .
$$


Selanjutnya, suku kedua dari Persamaan (35) bernilai nol karena integral $\hat{U}$ terbatas dan intervalnya sangat kecil. Berdasarkan definisi fungsi delta Dirac [7] $\int_{t=0}^{t+0} \delta(\tau-t) d \tau=1$ dan mensubstitusikan (34) ke Persamaan (35), diperoleh

$$
A_{2} \exp \left[\left(D \omega^{2}-i V \omega\right) t\right]-A_{1} \exp \left[\left(D \omega^{2}-i V \omega\right) t\right]=\exp (-i \omega x) .
$$

Perlu diingat bahwa $U$ menggambarkan distribusi panas pada $(\xi, \tau)$ yang disebabkan oleh unit dorongan panas positif pada $(x, t)$, karenanya $\hat{U}$ menyatakan distribusi panas di sepanjang koordinat waktu terbalik yang disebabkan oleh dorongan panas sesaat pada waktu $\tau=t$. Oleh karena itu, $\hat{\mathrm{U}}=0$ jika $\tau>t$. Berdasarkan keterangan tersebut berarti

$$
A_{1}=0
$$

sehingga pada Persamaan (36) diperoleh $A_{2}$, yaitu:

$$
A_{2}=\exp \left[-i \omega x-\left(D \omega^{2}-i V \omega\right) t\right]
$$

Selanjutnya, nilai $A_{1}$ dan $A_{2}$ yang telah diperoleh yaitu (37) dan (38) disubstitusikan kembali ke Persamaan (34), sehingga diperoleh

$$
\hat{\mathrm{U}}=\left\{\begin{array}{lr}
0 & , j i k a t-\tau<0 \\
\exp \left[-i \omega x-\left(D \omega^{2}-i V \omega\right) t\right] \cdot \exp \left[\left(D \omega^{2}-i \omega V\right) \tau\right], j i k a t-\tau>0
\end{array}\right.
$$

Jika dinyatakan dalam fungsi Heaviside [7]

maka Persamaan (39) dapat ditulis sebagai

$$
H(x-a)=\left\{\begin{array}{ll}
1, & \text { jika } x>a \\
0, & \text { jika } x<a
\end{array},\right.
$$

$$
\hat{\mathrm{U}}=\exp \left[-i \omega x-\left(D \omega^{2}-i V \omega\right)(t-\tau)\right] H(t-\tau) \text {. }
$$

Selanjutnya, mencari $U$ dengan membuat invers transformasi Fourier Persamaan (40) dari $\omega$ ke $\xi$, yaitu

$$
U(\xi, \tau)=\frac{1}{2 \pi} \int_{-\infty}^{\infty} \hat{\mathrm{U}} \exp (i \omega \xi) d \omega=\frac{H(t-\tau)}{2 \pi} \int_{-\infty}^{\infty} \exp \left\{-D(t-\tau)\left[\omega^{2}-i \omega \frac{(\xi-x)+V(t-\tau)}{D(t-\tau)}\right]\right\} d \omega .
$$

Dengan memisalkan

$$
\begin{aligned}
2 c & =i \frac{(\xi-x)+V(t-\tau)}{D(t-\tau)} \\
c & =i \frac{(\xi-x)+V(t-\tau)}{2 D(t-\tau)},
\end{aligned}
$$

lalu mensubstitusikan pemisalan (42) ke Persamaan (41), maka diperoleh

$$
\left.U(\xi, \tau)=\frac{H(t-\tau)}{2 \pi} \int_{-\infty}^{\infty} \exp \left[-D(t-\tau)(\omega-c)^{2}+D(t-\tau) c^{2}\right)\right] d \omega .
$$

Selanjutnya, dimisalkan

$$
\begin{gathered}
\zeta=\sqrt{D(t-\tau)}(\omega-c) \\
d \omega=\frac{1}{\sqrt{D(t-\tau)}} d \zeta .
\end{gathered}
$$

Jika pemisalan (45) dan (46) disubstitusikan ke Persamaan (44), maka diperoleh

$$
U(\xi, \tau)=\frac{H(t-\tau)}{2 \pi} \exp \left[D(t-\tau) c^{2}\right] \cdot \frac{1}{\sqrt{D(t-\tau)}} \int_{-\infty}^{\infty} \exp \left(-\zeta^{2}\right) d \zeta .
$$

Kemudian, pemisalan (43) disubstitusikan ke Persamaan (47) dan digunakan integral Gauss $\int_{-\infty}^{\infty} \exp \left(-\zeta^{2}\right) d \zeta=\sqrt{\pi}$, sehingga diperoleh hasil sebagai berikut:

$$
U(\xi, \tau ; x, t)=\frac{H(t-\tau)}{\sqrt{4 \pi D(t-\tau)}} \exp \left(-\frac{[(\xi-x)+V(t-\tau)]^{2}}{4 D(t-\tau)}\right) .
$$

Persamaan (48) adalah solusi dari (27) sekaligus solusi principal dari (24). 


\subsubsection{Solusi Reguler}

Setelah diperoleh solusi principal, maka selanjutnya akan dicari solusi reguler dari Persamaan (24). Solusi reguler $g$ dapat diperoleh dengan menyelesaikan persamaan homogen

$$
L^{*} g=-g_{\tau}-V g_{\xi}-D g_{\xi \xi}=0,-\infty<\xi<\infty, 0<\tau<\infty,
$$

dengan syarat batas (25)

$$
g(0, \tau)=\left.(G-U)\right|_{\xi=0} .
$$

Berdasarkan solusi principal (48), maka syarat batas (50) untuk Persamaan (49) dapat ditulis sebagai

$$
g(0, \tau)=\frac{-H(t-\tau)}{\sqrt{4 \pi D(t-\tau)}} \exp \left(-\frac{[x-V(t-\tau)]^{2}}{4 D(t-\tau)}\right) .
$$

Pendekatan inspeksi diperlukan untuk menyelesaikan solusi reguler dalam fungsi Green. Perlu diingat bahwa dalam fisika, solusi principal $U(\xi, \tau ; x, t)$ dari persamaan difusi-adveksi menggambarkan distribusi panas pada $(\xi, \tau)$ yang disebabkan oleh unit dorongan panas positif pada $(x, t)$. Dalam Persamaan (25), nilai fungsi Green harus nol pada titik asal. Untuk memenuhi kondisi tersebut, gambar sumber panas negatif dapat dirancang pada $(-x, t)$, seperti yang ditunjukkan pada Gambar 3, untuk mengimbangi nilai positif yang disebarkan dari $(x, t)$. Daya atau kekuatan dari sumber negatif sejauh ini belum jelas karena efek adveksi terbalik, tetapi dapat diasumsikan sebesar $\gamma$ kali unit dan $\gamma$ mungkin bergantung terhadap $(\xi, \tau)$, sehingga $\gamma=\gamma(\xi, \tau)$. Berdasarkan inspeksi, solusi Persamaan (49) diantisipasi dalam bentuk

$$
g(\xi, \tau)=-\gamma(\xi, \tau) U(\xi, \tau ;-x, t) .
$$

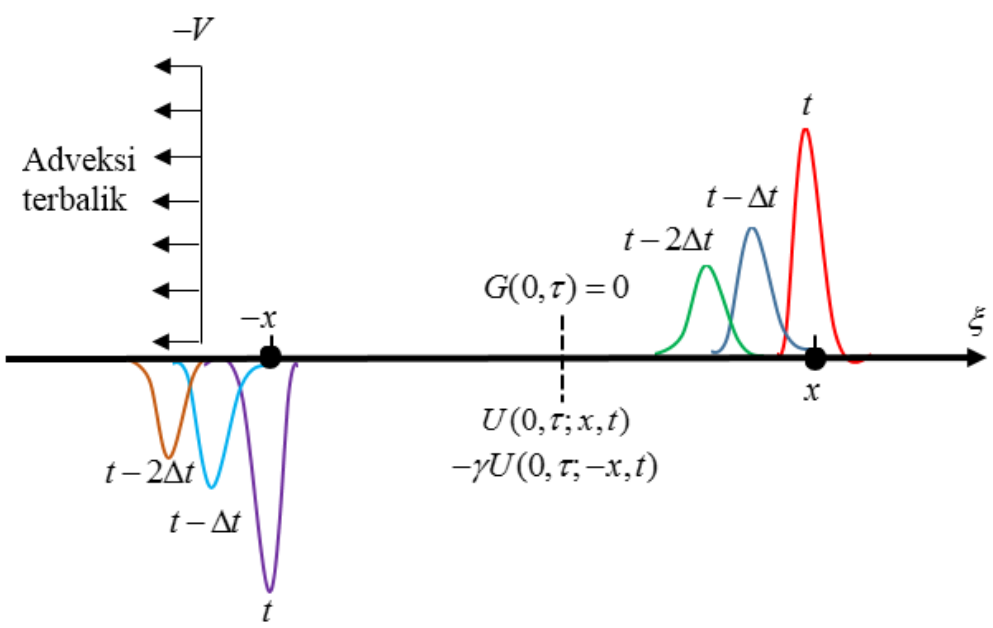

Gambar 3. Sistem Gambar Skematik untuk Masalah Difusi-Adveksi dengan Syarat Batas Dirichlet [15]

Syarat batas $g$ dalam (51) digunakan untuk menentukan $\gamma=\gamma(\xi, \tau)$. Berdasarkan (52) dan (48), maka diperoleh

$$
g(0, \tau)=-\gamma(0, \tau) U(0, \tau ;-x, t)=\frac{-H(t-\tau)}{\sqrt{4 \pi D(t-\tau)}} \exp \left(-\frac{[x-V(t-\tau)]^{2}}{4 D(t-\tau)}\right) \cdot \exp \left(-\frac{V x}{D}\right) \cdot \gamma(0, \tau) .
$$

Kemudian berdasarkan (51), diperoleh

$$
\begin{aligned}
& g(0, \tau)=g(0, \tau) \cdot \exp \left(-\frac{V x}{D}\right) \cdot \gamma(0, \tau) \\
& \gamma(0, \tau)=\exp \left(\frac{V x}{D}\right)
\end{aligned}
$$

Diketahui bahwa $\gamma$ adalah fungsi yang didefinisikan pada bidang $(\xi, \tau)$, tetapi sisi kanan (54) tidak mengandung $\xi$ dan $\tau$, hanya konstanta. Jadi, Persamaan (54) dapat ditulis sebagai

$$
\gamma(\xi, \tau) \equiv \exp \left(\frac{V x}{D}\right)
$$

Jadi, berdasarkan (55) dan (48), solusi reguler $g$ pada (52) adalah 


$$
g(\xi, \tau ; x, t)=-\frac{H(t-\tau)}{\sqrt{4 \pi D(t-\tau)}} \cdot \exp \left(\frac{V x}{D}\right) \cdot \exp \left(-\frac{[\xi+x+V(t-\tau)]^{2}}{4 D(t-\tau)}\right) .
$$

Solusi (56) diperoleh dengan pendekatan inspeksi, sehingga perlu dibuktikan bahwa (56) merupakan solusi dari (49). Adapun buktinya adalah sebagai berikut:

Pertama, jelas bahwa (56) memenuhi syarat batas (51). Kemudian akan dibuktikan bahwa (56) juga memenuhi Persamaan (49). Berdasarkan (56) dapat diperoleh turunan dari $g$ terhadap $\xi$ dan $\tau$, yaitu

$$
\begin{aligned}
& g_{\xi}=g \cdot\left[-\frac{[\xi+x+V(t-\tau)]}{2 D(t-\tau)}\right], \\
& g_{\xi \xi}=g \cdot\left[\frac{[\xi+x+V(t-\tau)]^{2}}{4 D^{2}(t-\tau)^{2}}-\frac{1}{2 D(t-\tau)}\right], \\
& g_{\tau}=g \cdot\left[\frac{1}{2(t-\tau)}+\frac{V^{2}}{4 D}-\frac{(\xi+x)^{2}}{4 D(t-\tau)^{2}}\right] .
\end{aligned}
$$

Jika Persamaan (57), (58), dan (59) disubstitusikan ke Persamaan (49), maka diperoleh

$$
-g_{\tau}-V g_{\xi}-D g_{\xi \xi}=0
$$

Dengan demikian, Persamaan (49) dipenuhi juga oleh (56). Jadi, terbukti bahwa solusi (56) yang diperoleh dengan inspeksi dalam fisika adalah solusi dari Persamaan (49).

Kembali ke Persamaan (24), baik solusi principal maupun solusi reguler keduanya telah diperoleh. Sehingga berdasarkan (26), (48), dan (56), diperoleh fungsi Green yaitu

$$
G(\xi, \tau ; x, t)=\frac{H(t-\tau)}{\sqrt{4 \pi D \cdot(t-\tau)}}\left[\exp \left(-\frac{[(\xi-x)+V \cdot(t-\tau)]^{2}}{4 D \cdot(t-\tau)}\right)-\exp \left(\frac{V x}{D}-\frac{[\xi+x+V \cdot(t-\tau)]^{2}}{4 D \cdot(t-\tau)}\right)\right]
$$

atau

$$
G(\xi, \tau ; x, t)=U(\xi, \tau ; x, t)-\exp \left(\frac{V x}{D}\right) U(\xi, \tau ;-x, t) .
$$

Solusi (60) atau (61) adalah fungsi Green pada domain semi-tak hingga dengan syarat batas Dirichlet. Setelah diperoleh fungsi Green, maka solusi dari Persamaan (18) dapat diperoleh dengan menyelesaikan integrasi dari Persamaan (23). Berikut contoh penggunaan fungsi Green untuk mendapatkan solusi dari persamaan difusi-adveksi dengan syarat batas Dirichlet.

Contoh 1. [15]

Diberikan masalah persamaan difusi-adveksi satu dimensi pada domain semi-tak hingga dengan syarat batas Dirichlet, yaitu

$$
\begin{gathered}
L u=u_{t}+V u_{x}-D u_{x x}=0,0<x<\infty, 0<t<\infty, \\
u(x, 0)=f(x)=0, \\
u(0, t)=h(t)=\sin (0.4 \pi t) .
\end{gathered}
$$

Dengan menerapkan konsep fungsi Green, maka diperoleh solusi dari Persamaan (62), yaitu

$$
u(x, t)=\int_{0}^{t}\left[D G_{\xi}(0, \tau) h(\tau)\right] d \tau .
$$

Nilai $G_{\xi}(0, \tau)$ diperoleh dengan menurunkan Persamaan (60) terhadap $\xi$ dan mensubstitusikan nilai $\xi=0$, yaitu

$$
\left.G_{\xi}(0, \tau)=\frac{1}{\sqrt{4 \pi D \cdot(t-\tau)}}\left\{\left[\frac{x-V \cdot(t-\tau)}{2 D .(t-\tau)}\right] \cdot \exp \left(-\frac{[x-V \cdot(t-\tau)]^{2}}{4 D \cdot(t-\tau)}\right)+\left[\frac{x+V \cdot(t-\tau)}{2 D \cdot(t-\tau)}\right] \cdot \exp \left(\frac{V x}{D}-\frac{[x+V \cdot(t-\tau)]^{2}}{4 D .(t-\tau)}\right)\right\}\right] d \tau
$$

Jika dimisalkan koefisien difusi $D=0,1 \mathrm{~cm}^{2} / \mathrm{s}$ dan kecepatan adveksi $\mathrm{V}=2 \mathrm{~cm} / \mathrm{s}$, serta mensubstitusikan Persamaan (64) dan (66) ke Persamaan (65), maka diperoleh solusi dari Persamaan (62) yaitu

$$
u(x, t)=\int_{0}^{t}\left[0,1 \sin (0.4 \pi \tau) \frac{1}{\sqrt{0,4 \pi(t-\tau)}}\left\{\left[\frac{x-2(t-\tau)}{0,2(t-\tau)}\right] \cdot \exp \left(-\frac{[x-2(t-\tau)]^{2}}{0,4(t-\tau)}\right)+\right.\right.
$$




$$
\left.\left[\frac{x+2(t-\tau)}{0,2(t-\tau)}\right] \cdot \exp \left(\frac{2 x}{0,1}-\frac{[x+2(t-\tau)]^{2}}{0,4(t-\tau)}\right)\right\} d \tau \text {. }
$$

Solusi analitik pada Persamaan (67) dapat diplotkan dengan menggunakan metode persegi panjang untuk menghitung integral pada nilai $t$ (dalam sekon) $=1,2,4$, dan 5 , seperti yang ditunjukkan oleh Gambar 4, berikut:

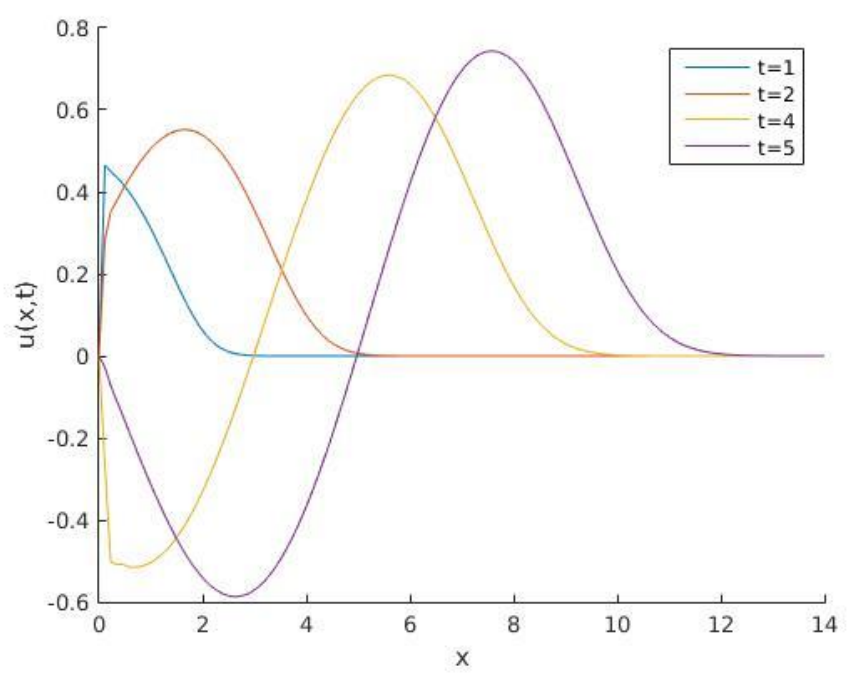

Gambar 4. Plot Solusi Analitik Persamaan Difusi-Adveksi dengan Syarat Batas Dirichlet

\section{KESIMPULAN}

Persamaan difusi-adveksi merupakan model matematika yang menggambarkan proses transportasi suatu zat yang dipengaruhi gaya gravitasi dan penyebaran sekaligus. Solusi dari persamaan difusi-adveksi dapat berbentuk fungsi Green. Fungsi Green diperoleh dari jumlahan solusi principal dan solusi reguler. Solusi principal diselesaikan menggunakan transformasi Fourier, kemudian menghitung invers dari transformasinya. Sedangkan, solusi reguler diperoleh dengan pendekatan inspeksi yang dirancang pada sumber panas negatif. Sehingga dari jumlahan kedua solusi tersebut, diperoleh fungsi Green untuk persamaan difusi-adveksi yaitu

$$
G(\xi, \tau ; x, t)=\frac{H(t-\tau)}{\sqrt{4 \pi D \cdot(t-\tau)}}\left[\exp \left(-\frac{[(\xi-x)+V \cdot(t-\tau)]^{2}}{4 D \cdot(t-\tau)}\right)-\exp \left(\frac{V x}{D}-\frac{[\xi+x+V .(t-\tau)]^{2}}{4 D .(t-\tau)}\right)\right],
$$

dengan $H(t-\tau)$ adalah fungsi Heaviside, $V$ adalah kecepatan adveksi dan $D$ adalah koefisien difusi.

\section{DAFTAR PUSTAKA}

[1] Anton, Howard dan Chris Rorres, Elementary Linear Algebra. USA: John Wiley \& Sons, Inc., 2005.

[2] Bleecker, David dan George Csordas, Basic Partial Differential Equations. New York: Van Nostrand Reinhold, 1992.

[3] Crank, J., The Mathematics of Diffusion. Oxford: Oxford University Press, 1975.

[4] Dorini, F.A. dan M.C.C Cunha, "On The Linear Advection Equation Subject to Random Velocity Fields," Mathematics and Computers in Simulation, vol. 82, no. 4, hal. 679-690, Desembar 2011.

[5] Duffy, Dean G., Green's Function with Applications. Boca Raton: Chapman \& Hall/CRC, 2001.

[6] Greenberg, Michael D., Applications of Green's Functions in Science and Engineering. Mineola: DoverPublications, 2015.

[7] Hoskins, R.F., Delta Functions: Introduction to Generalised Functions. Leicester: Woodhead Publishing, 2009.

[8] Kay, Anthony, "Advection-Diffusion in Reversing and Oscillating Flows: 1. The Effect of a Single Reversal," IMA Journal of Applied Mathematics, vol. 45, no. 2, hal. 115-137, Mei 1990. 
[9] Leij, Feike J., Eckart Priesack, dan Marcel G. Schaap, “Solute Transport modeled with Green's Functions with Application to Persistent Solute Sources," Journal of Contaminant Hydrology, vol. 41, no. 1-2, hal. 155-173, Januari 2000.

[10] Leveque, Randall J., Finite-Volume Methods for Hyperbolic Problems. Cambridge: Cambridge University Press, 2004.

[11] Okino, Takahisa, "Mathematical Physics in Diffusion Problems," Journal of Modern Physics, vol. 6, no. 14, hal. 2109-2144, November 2015.

[12] Roach, G.F., Green's Functions. Great Britain: Cambridge University Press, 1992.

[13] Rubin, Hillel dan Joseph F. Atkinson, Environmental Fluid Mechanics. New York: Marcel Dekker, 2001.

[14] Strauss, Walter A., Partial Differential Equations: An Introduction. USA: John Wiley \& Sons, Inc., 2007.

[15] Xu, Z., J.R. Travis dan W. Breitung, Green's Function Method and its Application to Verification of Diffusion Models of GASFLOW Code. Germany: Institut für Kern- und Energietechnik, 2007. 
